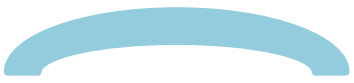

\title{
Lisansüstü Hemşirelik Öğrencilerinin Yenilikçi Özellikleri ile Araştırmaya Yönelik Farkındalıkları Arasındaki İlişki
}

\section{Relationship Between Innovativeness Characteristics and Research Awareness in Graduate Nursing Students}

\author{
Pelin KARAÇAY ${ }^{1 *}$ (D), Özlem YAZICI ${ }^{2}$ (D) , Ayda KEBAPCI ${ }^{10}$
}

${ }^{1}$ Koç Üniversitesi, Hemşirelik Fakültesi, İstanbul, Türkiye

${ }^{2}$ Okan Üniversitesi, Sağlık Bilimleri Fakültesi, Hemşirelik Bölümü, İstanbul, Türkiye

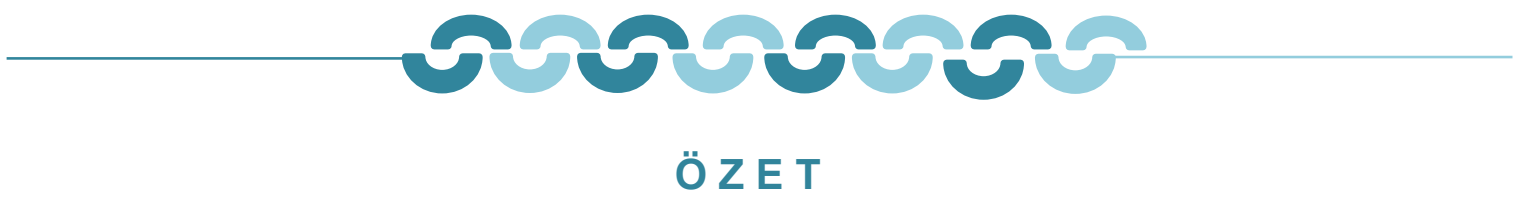

Amaç: Bu araştırmanın amacı, lisansüstü öğrencilerinin yenilikçilik özellikleri ile araştırmaya yönelik farkındalık ve tutumları arasındaki ilişki ve etkileyen faktörlerin belirlenmesidir.

Materyal Metot: Tanımlayıcı ve ilişki arayıc tipteki araştırma, bir vakıf üniversitesinin Hemşirelik Lisansüstü Programında kayıtlı, araştırmaya katılmaya gönüllü 226 öğrenci ile yapıldı. Araştırmanın verileri; öğrencilerin sosyo-demografik ve lisansüstü eğitim sürecine ilişkin özellikleri, Bireysel Yenilikçilik Ölçeği (BYÖ) ile Hemşirelik Öğrencilerinin Araştırmaya, Gelişmelere Farkındalığı ve Tutumu Ölçeği (HÖAGFTÖ)'nin yer aldığı veri toplama formu ile Qualtrics üzerinden oluşturulan bağlantı ile elektronik ortamda toplandı. Verilerinin analizinde; tanımlayıcı istatistikler, Kruskal-Wallis testi, Mann-Whitney $U$ testi, Bonferroni düzeltmeli MannWhitney U testi ve Spearman Rho Korelasyon Analizi kullanıldı.

Bulgular: Lisansüstü öğrencilerinin HÖAGFTÖ toplam puanları ile BYÖ toplam puanları $(r=0,428)$, fikir önderliği $(r=0,390)$, risk alma alt boyutları $(r=0,436)$ arasında pozitif yönde, değişime direnç alt boyutu puanları arasında ise negatif yönde $(r=-0,274)$ istatistiksel olarak anlamlı farklılık saptandı $(p<0,01)$. Kadınların, araştırma görevlisi/öğretim görevlisi olarak görev yapanların, bilimsel yayınları okuyanların, bilimsel yayınları üç ayda bir okuyanların ve kanıta dayalı bilgilere ulaşabildiğini düşünenlerin HÖAGFTÖ ve BYÖ puanları istatiksel olarak anlamlı düzeyde yüksek bulundu.

Sonuç: Lisansüstü öğrencilerinin bireysel yenilikçilik özellikleri ile araştırma farkındalık ve tutumları arasında orta düzeyde bir ilişki vardır. Lisansüstü öğrencilerinin BYÖ ve HÖAGFTÖ puanlarını etkileyebilecek ve çalışmada ele alınmayan faktörlerin araştırılması önerilir.

Anahtar Kelimeler: Hemşirelik öğrencileri, lisansüstü eğitim, araştırma farkındalık, yenilikçilik özellikler

Alınış / Received: 04.06.2021 Kabul / Accepted: 21.09.2021 Online Yayınlanma / Published Online: 20.12.2021 


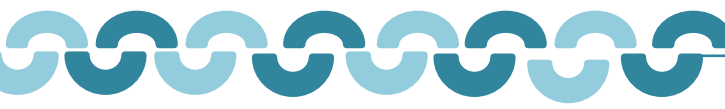

\section{A B S T R A C T}

Objectives: The aim of this study to determine the relationship between graduate students' innovative characteristics and their awareness and attitudes towards research.

Material-Method: This descriptive, correlational study was conducted with a total of 226 graduate nursing students. Data were collected with an online questionnaire regarding students' sociodemographic and academic characteristics and the Individual Innovativeness Scale (IIS) and Nursing Students' Attitudes and Awareness Towards Research and Development Scale (NSAATRDS). Data were analyzed using descriptive statistics, Mann Whitney-U test (with and without Bonferroni correction), Kruskal-Wallis test, and Spearman correlation.

Results: A statistically significant positive correlation was found between the students' total NSAATRDS scores and total IIS $(r=0,428)$ scores and between the ISS subscales of opinion leadership $(r=0,390)$ and risk taking $(r=0,436)$, while a negative correlation was found between NSAATRDS scores and the ISS subscale of resistance to change $(p<0,01)$. The scales scores of women, those working as research assistants/lecturers, those reading scientific publications, and those knowing how to access evidence-based information were found to be higher.

Conclusion: There is a moderate relationship between graduate students' individual innovativeness and their research awareness and attitudes. More studies are recommended to investigate factors affecting graduate students' individual innovativeness and research attitudes and awareness not included in this study.

Keywords: Nursing students, graduate education, research awareness, innovative characteristics

\section{Giriş}

Araştırma; sorgulama, öğrenme ve bilinmeyeni bilinene dönüştürme sürecidir. Bu süreç; problemin ve araştırma yönteminin belirlenmesi, çözüm önerilerinin tahmin edilmesi, verilerin toplanması, analiz edilmesi, karar verilmesi ve bulguların yorumlanmasını içerir. Kısaca araştırma, belirlenmiş süreçlerle yeni bilgilerin üretilmesi sürecidir [1]. Yenilikçilik ise "buluş ortaya koymak", "farklı olmak" ya da "yeni ve değişik bir şey yapmak" anlamlarına gelir [2]. Bir başka tanıma göre ise, bir organizasyon içinde yeni ürünlerin, hizmetlerin, prosedürlerin başarılı bir şekilde uygulanması ve yeni fikirlerin çıktılara dönüştürülmesi sürecidir [3].

Hemşirelik bölümü lisansüstü eğitim programları hemşirelerin yetkinliğinin sağlanmasında önemli bir role sahiptir [4]. Bu programların amacı, öğrencileri ileri hemşirelik uygulamaları ve liderlik için hazırlamak [5], yenilikçilik özellikleri ile araştırma odaklı tutum ve davranışları olan bireyler yetiştirmektir [1]. Lisansüstü eğitim veren bütün kurumlar; yenilikçi, sağlıkla ilgili politikalarda söz sahibi olacak, bulundukları kurumlarda değişim ajanı olabilecek, bilimsel kanıtlar üretebilecek ve sağlık bakım kalitesinin arttırılmasına katkıda bulunacak insan gücünü yetiştirmeyi hedeflenmektedir [2,6]. Bu nedenle, lisansüstü eğitim sürecinde, öğrencilerin yenilikçilik özelliklerini ve araştırma becerilerini geliştirecek stratejilerin planlanması gereklidir [2,7]. Bu planlamaların yapılabilmesi için de kurumlar en iyi koşulları ve kaynakları sunarak, danışmanlar aracılığı ile öğrencilerin akademik ve klinik deneyim elde etmelerine önemli ölçüde katkıda bulunurlar [4].

Yüksek lisans tezini bitiren 322 mezun ile yapılan bir çalışmada, mezunlar yüksek lisans tezinin bir parçası olan küçük çapta bir araştırma yapmalarının araştırma becerilerine olumlu katkıda bulunduğunu, mesleki uygulamalara yönelik araştırma anlayışı ve uygulaması konusunda gelişmekle birlikte çalışmalarını yazma, planlama ve problem çözme becerilerinde de geliştiklerini ifade etmişlerdir 
[8]. Lisansüstü öğrenciler ve danışmanları ile yapılan bir başka çalışmada, tez danışmanlarının "öğrencilerin araştırma yapabilmelerine inancı" ile öğrencilerin "araştırma yapabilmeye olan inançları" arasında anlamlı bir fark olduğu bulunmuştur. Bu farkın da, danışmanların öğrencilerin araştırma yapabilmelerine inançlarının öğrencilerin kendilerine olan inançlarından daha yüksek olmasından kaynaklandığı belirlenmiş̧tir ${ }^{(9)}$. Havenga ve Sengane (2018) lisansüstü öğrencileri ile yaptıkları bir çalışmada ise, öğrencilerin bilimsel kaynaklara ulaşma yollarını bilmediklerinden dolayı araştırma ile ilgili zorluklar yaşadıklarını saptamıştır [5].

Araştırma ve yenilikçilik kavramlarının birbirleri ile ilişkili kavramlar olduğu düşünülmektedir. Ancak lisansüstü hemşirelik öğrencilerinin yenilikçilik yaklaşımları ile araştırma farkındalık ve tutumları arasındaki ilişkiyi ortaya koyan bir çalışmaya literatürde rastlanmamıştır. Bu çalışma, lisansüstü hemşirelik öğrencilerinin yenilikçilik yaklaşımları ile araştırma, gelişmelere yönelik farkındalık ve tutumları arasındaki ilişki ve etkileyen faktörlerin belirlenmesi amacıyla planlanmıştır. Bu çalışma, eğitimcilere yenilikçi özelliklere, araştırma farkındalık ve tutuma sahip hemşireleri ve akademisyenleri nasıl geliştirebilecekleri konusunda rehberlik ederek, lisansüstü eğitim müfredatlarının yeniden şekillendirilmesine katkı sağlayabilir.

\section{Materyal ve Metot}

\section{Araştırmanın Tipi}

Bu araştırma tanımlayıcı ve ilişki arayıcı tiptedir.

\section{Araştırmanın Amacı}

Bu çalışmanın amacı, lisansüstü hemşirelik öğrencilerinin yenilikçilik özellikleri ile araştırma, gelişmelere karşı farkındalık ve tutumları arasındaki ilişki ve etkileyen faktörlerin belirlenmesidir.

\section{Araştırma Soruları}

1. Lisansüstü hemşirelik öğrencilerinin yenilikçilik özellikleri nasıldır?

2. Lisansüstü hemşirelik öğrencilerinin araştırma, gelişmelere karşı farkındalık ve tutum düzeyleri nasıldır?

3. Lisansüstü hemşirelik öğrencilerinin yenilikçilik özellikleri ile araştırma, gelişmelere yönelik farkındalık ve tutumları arasında ilişki var mıdır?

4. Lisansüstü hemşirelik öğrencilerinin yenilikçilik özelliklerini etkileyen faktörler nelerdir?

5. Lisansüstü hemşirelik öğrencilerinin araştırma, gelişmelere yönelik farkındalık ve tutum düzeylerini etkileyen faktörler nelerdir?

\section{Evren ve Örneklem}

Araştırmanın evrenini, 2018-2019 akademik öğretim yılında bir vakıf üniversitesinin Hemşirelik Lisansüstü Programına kayıtlı toplam 450 öğrenci oluşturdu. Araştırmanın örneklemini ise çalışmaya katımaya gönüllü öğrenciler dahil edildi. Araştırmanın örneklemi G Power 3.1.9 programı ile hesaplandı. Yapılan hesaplamada, araştırmanın örneklemi 0.05 standart hata oranı ve \%95 güven aralığı dikkate alınarak, örneklem sayısı 207 öğrenci olarak belirlendi. Araştırma toplam 226 lisansüstü hemşirelik öğrencisi ile yapıldı. Eksik doldurulan 53 form değerlendirmeye alınmadı.

\section{Veri Toplama Araçları}

Araştırmanın verileri üç bölümden oluşan veri toplama formu ile toplandı. Birinci bölümde, öğrencilerin sosyo-demografik ve lisansüstü eğitim sürecine ilişkin özellikleri, ikinci bölümde, Bireysel Yenilikçilik Ölçeği (BYÖ), üçüncü bölümde ise Hemşirelik Öğrencilerinin Araştırmaya, Gelişmelere Farkındalığı ve Tutumu Ölçeği (HÖAGFTÖ) yer aldı.

\section{Sosyo-Demografik ve Lisansüstü Eğitime İlişkin Özellikler}

Bu form; öğrencinin yaşı, cinsiyeti, medeni durumu, hangi dönemde olduğu (yüksek lisans ders/tez dönemi, doktora ders/tez dönemi), görevi, mesleki deneyim süresi, istatistik ve araştırma ile ilgili ders alma durumu, alınan derslerin adları, tezi dışında araştırma deneyimi olma durumu, bilimsel yayınları takip etme durumu, bilimsel yayınları okuma sıkığı ve kanıta dayalı bilgilere ulaşabileceğini düşünme durumu olmak üzere toplam 12 sorudan oluşmaktadır. 


\section{Bireysel Yenilikçilik Ölçeği (BYÖ)}

BYÖ bireylerin yenilikçiliğini değerlendirmek için Hurt ve arkadaşları (1977) [10] tarafından geliştirilmiş, Sarıoğlu ve Altuntaş (2014) tarafından Türkçe geçerlik ve güvenirlik uyarlama çalışması yapılmıştır. Ölçek 18 madde ve fikir önderliği, değişime direnç ve risk alma olmak üzere 3 alt boyuttan oluşmaktadır. 5'li likert tipindeki ölçekte verilebilecek cevaplar 1-Kesinlikle Katılmıyorum, 2Katılmıyorum, 3-Kararsızım, 4-Katılıyorum, 5-Kesinlikle Katılıyorum şeklindedir. Ölçek toplam ve alt boyut puanı her maddeden alınan puanların toplamından elde edilmektedir. Ölçekten alınabilecek toplam puan 18-90 arasında değişmektedir. Ölçekten elde edilen puan 46'nın altında ise "gelenekçi", 46-56 arasında ise "kuşkucu", 57-68 arasında ise "sorgulayıcı", 69-80 arasında ise "öncü", 80'in üzerinde ise "yenilikçi" olarak değerlendirilmektedir. Uyarlama çalışmasında ölçeğin genel Cronbach alfa değeri 0.82 , fikir önderliği alt boyutunun 0.80 , değişime direnç alt boyutunun 0.78 , risk alma alt boyutunun ise 0.72 'diR [7]. Bu çalışmada ise ölçeğin genel Cronbach alfa değeri 0.84 , fikir önderliği alt boyutunun 0.82 , değişime direnç alt boyutunun 0.73 , risk alma alt boyutunun 0.67 'dir.

\section{Hemşirelik Öğrencilerinin Araştırmaya, Gelişmelere Farkındalığı ve Tutumu Ölçeği (HÖAGFTÖ)}

Temel ve arkadaşları (2008) tarafından Türkçe geçerlik ve güvenilirlik uyarlama çalışması yapılan ölçek, 29 maddeden oluşmaktadır. Bu maddelerin, 17'si olumlu ve 12'si ise olumsuz'dur. Ölçek 5'li likert tipinde ve verilebilecek cevaplar; 5-Çok Katılıyorum, 4-Katılıyorum, 3-Kısmen Katılıyorum 2-Çok Az Katılıyorum, 1-Hiç Katılmıyorum şeklindedir. Ölçekteki ters maddelerde puanlar tersine çevrilmekte ve bütün maddeler 1-5 arası puanlanmaktadır. Ölçekten alınabilecek puan 29-145 arasında değişiklik göstermektedir. Ölçekten alınan puanın yüksek olması, öğrencilerin araştırma, gelişmelere karşı tutumlarının olumlu olduğu anlamına gelmektedir. Temel ve arkadaşları (2008)'nın çalışmasında ölçeğin Cronbach alpha değeri 0.89 'dur [11]. Bu çalışmada ise, ölçeğin genel Cronbach alfa değeri $0.88^{\prime}$ dir.

\section{Araştırmanın Etik Yönü}

Ölçekleri Türkçe'ye uyarlayan birinci yazarlardan elektronik posta ile izin alındı. Araştırmanın uygulanması için Koç Üniversitesi Sosyal Bilimler Araştırmaları Etik Kurulu'ndan (2019.171.IRB3.101) onay ve araştırmaya katılmayı kabul eden öğrencilerden araştırmanın elektronik bağlantısı üzerinden izin alınmıştır. Öğrenciler, istedikleri zaman araştırmadan ayrılma ve cevaplamak istemedikleri soruları geçebilme hakkına sahipti.

\section{Verilerin Toplanması}

Çalışmanın verileri, Haziran-Aralık 2019 tarihleri arasında toplandı. Lisansüstü hemşirelik öğrencilerine elektronik posta yolu ile ulaşıldı. Çalışmanın bağlantısı elektronik ortamda "Qualtrics" üzerinden oluşturuldu ve öğrencilerin e-maillerine gönderildi. Öğrencilere 21 gün aralıklarla üç kez hatırlatma emailleri gönderildi. Öğrenciler bağlantıyı tıkladıklarında önlerine bilgilendirme metni geldi. Araştırmaya katılmak isteyen öğrenciler, bu bilgilendirmeyi okuduktan ve "Evet araştırmaya katılmak istiyorum" seçeneğini işaretledikten sonra isimleri belli olmadan elektronik ortamda soruları cevaplamaya başladılar. Soruların cevaplanması yaklaşık 15-20 dk sürdü.

\section{Verilerin Analizi}

Araştırmada verilerin analizi için SPSS for Windows 26.0 (Statistical Package for the Social Sciences) programı kullanıldı. Değişkenlerin normal dağılıma uygunluğu Kolmogorov Smirnov testi, Q-Q grafikler ve histogramlar ile değerlendirildi. Ölçek alt boyut ve toplam puanlarının dağılımının, normal dağılımdan istatistiksel olarak anlamlı farklılık gösterdiği saptandı $(p<0,05 ; p<0,01)$. Bu durum, ölçeklerde hesaplanan puanların normal dağılmadığını gösterdi. Çalışma verileri değerlendirilirken tanımlayıcı istatistiksel metotlar (ortalama, medyan, standart sapma), normal dağılım göstermeyen niceliksel verilerin iki grup arası değerlendirmelerinde Mann-Whitney $U$ testi, ikiden fazla grup arası değerlendirmelerinde ise Kruskal-Wallis testi kullanıldı. Farklıı̆ga neden olan grubun tespit edilmesinde Bonferroni düzeltmeli Mann-Whitney $U$ testi kullanıırken, ölçek puanları arasındaki ilişki ise Spearman Rho Korelasyon Analizi ile değerlendirildi. Anlamlılık $p<0,05$ düzeyinde değerlendirildi. 


\section{Bulgular}

Araştırma kapsamına alınan toplam 226 lisansüstü hemşirelik öğrencisinin verileri analiz edildi. Buna göre, öğrencilerin yaş ortalaması 29,35 (SS=5,18; min-max: 22-45) yıl, \%77,4'ünün ( $n=175)$ kadın, $\% 81$ 'inin $(n=183)$ bekar olduğu, \%54,3'ünün $(n=123)$ tezli Yüksek Lisans $(Y L)$ ders döneminde olduğu, $\% 76,1^{\prime}$ 'inin $(n=172)$ hemşire olarak çalıştığı ve meslekte çalışma süresinin ortalamasının 6,84 yıl (SS=5,73; min-max:0,25-28) olduğu belirlendi (Tablo 1).

Tablo 1. Öğrencilerin sosyo-demoğrafik özellikleri (N=226)

\begin{tabular}{|c|c|c|c|}
\hline Özellikler & & Min-Maks & OrttSS \\
\hline Yaş & & $22-45$ & $29,35 \pm 5,18$ \\
\hline \multirow[t]{2}{*}{ Meslekte çalışma süresi (yıl) } & & $0,25-28$ & $6,84 \pm 5,73$ \\
\hline & & $\mathbf{N}$ & $\%$ \\
\hline \multirow{2}{*}{ Cinsiyet } & Kadın & 175 & 77,4 \\
\hline & Erkek & 51 & 22,6 \\
\hline \multirow{2}{*}{ Medeni durum } & Bekar & 183 & 81,0 \\
\hline & Evli & 43 & 19,0 \\
\hline \multirow{4}{*}{ Dönem } & YL tez dönemi & 123 & 54,3 \\
\hline & YL ders dönemi & 84 & 37,2 \\
\hline & $\begin{array}{ll}\text { Doktora } & \text { ders } \\
\text { dönemi } & \end{array}$ & 13 & 5,8 \\
\hline & $\begin{array}{ll}\text { Doktora } & \text { tez } \\
\text { dönemi } & \end{array}$ & 6 & 2,7 \\
\hline \multirow{5}{*}{ Görev } & Hemşire & 172 & 76,1 \\
\hline & $\begin{array}{l}\text { Servis sorumlu } \\
\text { hemşiresi }\end{array}$ & 16 & 7,1 \\
\hline & $\begin{array}{l}\text { Araştırma } \\
\text { görevlisi }\end{array}$ & 4 & 1,8 \\
\hline & Öğretim görevlisi & 9 & 4,0 \\
\hline & Diğer & 25 & 11,1 \\
\hline
\end{tabular}

Ort:Ortalama; SS: Standart sapma Min-max: Minumun-maxium

Öğrencilerin \%99,1'inin ( $n=224)$ lisansüstü eğitim süresince istatistik ve araştırma ile ilgili ders aldığı ve bu öğrencilerin \%25'inin $(n=56)$ araştırma yöntemleri, \%93,3'ünün $(n=209)$ biyoistatistik ve $\% 74,6$ 'sının ( $n=167)$ epidemiyoloji dersi aldıkları saptandı. Öğrencilerin \%42,9'unun ( $n=97)$ lisansüstü eğitimi süresince tez dışında bir araştırma deneyiminin olduğu, \%66,8'inin ( $n=151$ ) hemşirelik araştırmaları ile ilgili bilimsel yayınları takip ettiği, \%25,7'sinin bu yayınları $(n=58) 3$ ayda bir okuduğu ve \%73'ünün ( $n=165)$ kanıta dayalı uygulamalara ulaşmayı bildiğini düşündüğü saptandı.

Lisansüstü hemşirelik öğrencilerinin BYÖ toplam puanlarının ortalaması 70,35, alınan puan 69-80 arasında olduğu için "öncü" özelliklere sahip oldukları (SS=8,23; min-max:36-90) ve HÖAGFTÖ toplam puanlarının ortalamasının 129,22 ( $S S=1,65$; min-max: 88-145) olduğu saptandı. Lisansüstü hemşirelik öğrencilerinin BYÖ fikir önderliği alt boyutu puan ortalamasının 27,34 (SS=4,01; minmax:16-35), değişime direnç alt boyutu puan ortalamasının 15,84 (SS=4,26; min-max:7-31) ve risk alma alt boyutu puan ortalamasının 16,85 (SS=2,03; min-max:7-31) olduğu belirlendi.

HÖAGFTÖ toplam puanları ile BYÖ toplam $(r=0,428 ; p=0,001)$ puanları, fikir önderliği $(r=0,390$; $p=0,001)$, risk alma $(r=0,436 ; p=0,001)$ alt boyutları arasında pozitif yönde $(p<0,01)$, HÖAGFTÖ 
toplam puanları ile değişime direnç alt boyutu puanları arasında ise negatif yönde $(r=-0,274 ; p=0,001)$ istatistiksel olarak anlamlı farklılık saptandı $(p<0,01)$ (Tablo 2$)$.

Tablo 2. Öğrencilerin BYÖ ve HÖAGFTÖ puanları arasındaki ilişki

\begin{tabular}{|l|c|c|}
\hline \multirow{2}{*}{ BYÖ } & \multicolumn{2}{|c|}{ HÖAGFTÖ Toplam } \\
\cline { 2 - 3 } & $\mathrm{r}$ & $\mathrm{p}$ \\
\hline Fikir önderliği & 0,390 & $0,001^{\text {** }}$ \\
\hline Değişime direnç & $-0,274$ & $0,001^{\text {**}}$ \\
\hline Risk alma & 0,436 & $0,001^{\text {** }}$ \\
\hline Toplam & 0,428 & $0,001^{\text {** }}$ \\
\hline
\end{tabular}

r: Spearman Rho Korelasyon Katsayısı ${ }^{* *} p<0,01 ;$ BYÖ: Bireysel Yenilikçilik Ölçeği; HÖAGFTÖ: Hemşirelik Öğrencilerinin Araştırmaya, Gelişmelere Farkındalığı ve Tutumu Ölçeğı

Öğrencilerin sosyo-demografik özelliklerine göre HÖAGFTÖ puanları karşılaştırıldığında; kadınların HÖAGFTÖ toplam puanları, erkeklerden istatistiksel olarak anlamlı düzeyde yüksek saptanırken $(p<0,01)$ HÖAGFTÖ toplam puanları açısından lisansüstü hemşirelik öğrencilerinin görevleri arasında istatiksel olarak anlamlı farklıık saptandı $(p<0,05)$. Buna göre, öğrencilerin görevleri arasında araştırma görevlisi veya öğretim görevlisi olarak çalışanların HÖAGFTÖ toplam puanları, hemşire $(p=0,003)$, servis sorumlu hemşiresi $(p=0,002)$ ve diğer görevlerde $(p=0,012)$ çalışanlardan anlamlı şekilde yüksek saptandı $(p<0,017)$. Öğrencilerin sosyo-demografik özelliklerine göre BYÖ puanları karşılaştırıldığında ise, lisansüstü hemşirelik öğrencilerinin görevleri arasında BYÖ risk alma alt boyutu puanları açısından istatistiksel olarak anlamlı farklılık saptandı $(p<0,05)$. Buna göre, araştırma görevlisi veya öğretim görevlisi olarak görev yapanların risk alma alt boyutu puanları, hemşire $(p=0,002)$, servis sorumlu hemşiresi $(p=0,009)$ ve diğer görevlerde $(p=0,002)$ çalışanlardan istatistiksel olarak anlamlı düzeyde yüksek saptandı $(p<0,017)$ (Tablo 3 ).

Tablo 3. Öğrencilerin sosyo-demografik özelliklerine göre BYÖ ve HÖAGFTÖ puanlarının karşılaştırılması

\begin{tabular}{|c|c|c|c|c|c|c|}
\hline \multirow{3}{*}{\multicolumn{2}{|c|}{$\begin{array}{l}\text { Sosyo-demografik } \\
\text { özellikler }\end{array}$}} & \multicolumn{4}{|c|}{ BYÖ } & \multirow{2}{*}{$\begin{array}{c}\text { HÖAGFTÖ } \\
\text { Toplam }\end{array}$} \\
\hline & & \multirow{2}{*}{$\begin{array}{c}\text { Fikir } \\
\text { önderliği }\end{array}$} & \multirow{2}{*}{$\begin{array}{c}\begin{array}{c}\text { Değişime } \\
\text { direnç }\end{array} \\
\text { Medyan } \\
\text { (Q1-Q3) }\end{array}$} & \multirow{2}{*}{$\begin{array}{l}\text { Risk alma } \\
\text { Medyan } \\
\text { (Q1-Q3) }\end{array}$} & \multirow{2}{*}{$\begin{array}{l}\text { Toplam } \\
\text { Medyan } \\
\text { (Q1-Q3) }\end{array}$} & \\
\hline & & & & & & Medyan (Q1-Q3) \\
\hline \multirow{4}{*}{$\begin{array}{l}\text { Yaş } \\
\text { grubu }\end{array}$} & $<30 \mathrm{yll}$ & $27(25-30)$ & $16(13-19)$ & $17(16-18)$ & $70(65-75)$ & $\begin{array}{c}131(124,25- \\
137)\end{array}$ \\
\hline & $\geq 30$ yıl & $\begin{array}{c}27,5(25,7- \\
30)\end{array}$ & $15(12-18)$ & $17(16-19)$ & $70(65-78)$ & $\begin{array}{c}131(125,75- \\
139)\end{array}$ \\
\hline & Z & $-0,630$ & $-1,691$ & $-0,770$ & $-1,023$ & $-0,304$ \\
\hline & $p$ & 0,529 & 0,091 & 0,442 & 0,306 & 0,761 \\
\hline \multirow{4}{*}{$\begin{array}{l}\text { Cinsiye } \\
t\end{array}$} & Kadın & $27(25-30)$ & $16(13-18)$ & $17(16-18)$ & 70 (65-77) & $132(127-138)$ \\
\hline & Erkek & $27(25-31)$ & $16(12-19)$ & $17(16-19)$ & $71(64-76)$ & $126(116-133)$ \\
\hline & Z & $-0,042$ & $-0,387$ & $-0,359$ & $-0,071$ & $-3,234$ \\
\hline & $p$ & 0,967 & 0,699 & 0,719 & 0,944 & $0,001^{* *}$ \\
\hline \multirow{4}{*}{$\begin{array}{l}\text { Medeni } \\
\text { durum }\end{array}$} & Bekar & $27(25-30)$ & $16(13-18)$ & $17(16-18)$ & $70(66-76)$ & $131(124-138)$ \\
\hline & Evli & $28(24-31)$ & $15(12-18)$ & $16(16-18)$ & $69(65-78)$ & $132(129-137)$ \\
\hline & $\bar{Z}$ & $-0,004$ & $-0,542$ & $-1,276$ & $-0,073$ & $-1,130$ \\
\hline & $p$ & 0,997 & 0,588 & 0,202 & 0,942 & 0,258 \\
\hline
\end{tabular}




\begin{tabular}{|c|c|c|c|c|c|c|}
\hline \multirow{6}{*}{ Dönem } & $\begin{array}{l}\text { Tezli YL } \\
\text { ders dönemi }\end{array}$ & $27(24-30)$ & $16(13-18)$ & $\begin{array}{c}16,5(16- \\
18)\end{array}$ & $\begin{array}{l}69(65- \\
76,75)\end{array}$ & $\begin{array}{c}131(123,25- \\
137)\end{array}$ \\
\hline & Tezli YL tez & $28(26-29)$ & $16(13-19)$ & $17(16-18)$ & $70(65-76)$ & $131(125-138)$ \\
\hline & $\begin{array}{l}\text { Doktora ders } \\
\text { dönemi }\end{array}$ & $\begin{array}{c}28(22,5- \\
31,5)\end{array}$ & $14(12-16)$ & $18(16-19)$ & $\begin{array}{c}75(67,5- \\
79)\end{array}$ & $\begin{array}{c}131(129,5- \\
141,5)\end{array}$ \\
\hline & $\begin{array}{l}\text { Doktora tez } \\
\text { dönemi }\end{array}$ & $\begin{array}{c}28(26,75- \\
32)\end{array}$ & $\begin{array}{c}12,5(11- \\
19,5)\end{array}$ & $\begin{array}{c}18,5(16- \\
20)\end{array}$ & $\begin{array}{c}76,5 \\
(64,75- \\
82,25)\end{array}$ & $137(130,5-143)$ \\
\hline & $x^{2}$ & 1,921 & 3,549 & 3,754 & 2,650 & 6,163 \\
\hline & $p$ & 0,589 & 0,314 & 0,289 & 0,449 & 0,104 \\
\hline \multirow{6}{*}{ Görev } & Hemşire & $27(25-30)$ & $16(13-19)$ & $17(16-18)$ & $70(65-76)$ & 131 (124-137) \\
\hline & $\begin{array}{l}\text { Servis } \\
\text { sorumlu } \\
\text { hemşiresi }\end{array}$ & $\begin{array}{c}27(24,25- \\
28,75)\end{array}$ & $\begin{array}{c}15(13,25- \\
16,5)\end{array}$ & $16(16-18)$ & $\begin{array}{c}70(67,25- \\
76,25)\end{array}$ & $\begin{array}{c}128,5(121- \\
132,75)\end{array}$ \\
\hline & $\begin{array}{l}\text { Araştırma/ } \\
\text { Öğretim } \\
\text { görevlisi }\end{array}$ & $\begin{array}{c}29(27- \\
30,5)\end{array}$ & $14(11-15)$ & $\begin{array}{c}19(17,5- \\
20)\end{array}$ & $75(71-80)$ & $140(133-141)$ \\
\hline & Diğer & $\begin{array}{c}27(24,5- \\
29,5)\end{array}$ & $17(12-18)$ & $16(16-18)$ & $69(65-77)$ & $131(129,5-137)$ \\
\hline & $x^{2}$ & 2,484 & 4,580 & 10,892 & 5,470 & 11,173 \\
\hline & $p$ & 0,478 & 0,205 & $0,012^{*}$ & 0,140 & $0,011^{*}$ \\
\hline \multirow{4}{*}{$\begin{array}{l}\text { Meslek } \\
\text { te } \\
\text { çalışm } \\
\text { a } \\
\text { süresi }\end{array}$} & $\leq 5 \mathrm{yll}$ & $27(25-30)$ & $16(13-18)$ & $17(16-18)$ & $70(66-76)$ & $131(126-138)$ \\
\hline & $>5 \mathrm{yll}$ & 27 (24-29) & $15(12-18)$ & $16(16-18)$ & 70 (65-77) & $131(123-137)$ \\
\hline & Z & $-0,755$ & $-1,345$ & $-1,140$ & $-0,140$ & $-1,116$ \\
\hline & $p$ & 0,450 & 0,179 & 0,254 & 0,889 & 0,265 \\
\hline
\end{tabular}

Z: Mann Whitney-U Testi $X^{2}:$ Kruskal-Wallis Testi ${ }^{*} p<0,05{ }^{* *} p<0,01$

YL: Yüksek Lisans; BYÖ: Bireysel Yenilikçilik Ölçeği; HÖAGFTÖ: Hemşirelik Öğrencilerinin Araştırmaya, Gelişmelere Farkındalığı ve Tutumu Ölçeği

Öğrencilerin lisansüstü eğitim özelliklerine göre HÖAGFTÖ puanları karşılaştırıldığında; bilimsel yayınları okuma sıklıklarına göre HÖAGFTÖ toplam puanları açısından istatistiksel olarak anlamlı farklııık saptandı $(p<0,01)$. Haftada bir bilimsel yayın okuyanların HÖAGFTÖ toplam puanları, yılda bir $(p=0,001), 3$ ayda bir $(p=0,001)$, ayda bir $(p=0,001)$ bilimsel yayın okuyanlardan ve hiç bilimsel yayın okumayanlardan $(p=0,001)$ anlamlı düzeyde yüksek saptandı $(p<0,017)$. Ayda bir bilimsel yayın okuyanların HÖAGFTÖ toplam puanları, yılda bir $(p=0,001), 3$ ayda bir $(p=0,001)$ ve hiç dergi okumayanlardan $(p=0,001)$ anlamlı düzeyde yüksek saptandı $(p<0,017)$. Ayrıca, kanıta dayalı uygulamalara nasıl ulaşacağını bildiğini düşünen öğrencilerin HÖAGFTÖ toplam puanları, bilmediğini düşünen öğrencilerden istatistiksel olarak anlamlı düzeyde yüksek saptandı $(p<0,01)$ (Tablo 4). 
Tablo 4. Öğrencilerin lisansüstü eğitim özelliklerine göre BYÖ ve HÖAGFTÖ puanlarının karşılaştırılması

\begin{tabular}{|c|c|c|c|c|c|c|}
\hline \multirow{4}{*}{\multicolumn{2}{|c|}{$\begin{array}{l} \\
\text { Lisansüstü eğitim sürecine } \\
\text { ilişkin özellikler }\end{array}$}} & \multicolumn{4}{|c|}{ BYÖ } & \multirow{2}{*}{$\begin{array}{c}\text { HÖAGFTÖ } \\
\text { Toplam }\end{array}$} \\
\hline & & \multirow{3}{*}{$\begin{array}{l}\text { Fikir önderliği } \\
\text { Medyan } \\
\text { (Q1-Q3) }\end{array}$} & \multirow{3}{*}{$\begin{array}{c}\text { Değişime } \\
\text { direnç } \\
\text { Medyan } \\
\text { (Q1-Q3) }\end{array}$} & \multirow{3}{*}{$\begin{array}{l}\text { Risk alma } \\
\text { Medyan } \\
\text { (Q1-Q3) }\end{array}$} & \multirow{3}{*}{$\begin{array}{l}\text { Toplam } \\
\text { Medyan } \\
\text { (Q1-Q3) }\end{array}$} & \\
\hline & & & & & & Medyan \\
\hline & & & & & & (Q1-Q3) \\
\hline \multirow{4}{*}{$\begin{array}{l}\text { İstatistik ve } \\
\text { araştırma ile } \\
\text { ilgili ders alma } \\
\text { durumu }\end{array}$} & Evet & $\begin{array}{c}27 \\
(25-30)\end{array}$ & $\begin{array}{c}16 \\
(13-18)\end{array}$ & $\begin{array}{c}17 \\
(16-18)\end{array}$ & $\begin{array}{c}70 \\
(65-77)\end{array}$ & $\begin{array}{c}131 \\
(125-138)\end{array}$ \\
\hline & Hayır & $\begin{array}{c}29,5 \\
(27-32)\end{array}$ & $\begin{array}{c}15 \\
(13-17)\end{array}$ & $\begin{array}{c}16,5 \\
(16-17)\end{array}$ & $\begin{array}{c}73 \\
(68-78)\end{array}$ & $\begin{array}{c}120,5 \\
(115-126)\end{array}$ \\
\hline & Z & $-0,769$ & $-0,300$ & $-0,289$ & $-0,473$ & $-1,539$ \\
\hline & $p$ & 0,442 & 0,764 & 0,773 & 0,636 & 0,124 \\
\hline \multirow{4}{*}{$\begin{array}{l}\text { Araştırma } \\
\text { yöntemleri } \\
\text { dersi alma } \\
\text { durumu }\end{array}$} & Evet & $\begin{array}{c}28 \\
(26-31)\end{array}$ & $\begin{array}{c}15,5 \\
(12-19)\end{array}$ & $\begin{array}{c}17 \\
(16-19)\end{array}$ & $\begin{array}{c}71 \\
(65,5-78)\end{array}$ & $\begin{array}{c}132,5 \\
(128-138,75)\end{array}$ \\
\hline & Hayır & $\begin{array}{c}27 \\
(25-29)\end{array}$ & $\begin{array}{c}16 \\
(13-18)\end{array}$ & $\begin{array}{c}16 \\
(16-18)\end{array}$ & $\begin{array}{c}70 \\
(65-76)\end{array}$ & $\begin{array}{c}131 \\
(124-137,25)\end{array}$ \\
\hline & Z & $-1,462$ & $-0,059$ & $-1,529$ & $-1,078$ & $-1,661$ \\
\hline & $p$ & 0,144 & 0,953 & 0,126 & 0,281 & 0,097 \\
\hline \multirow{4}{*}{$\begin{array}{l}\text { Biyoistatistik } \\
\text { dersi alma } \\
\text { durumu }\end{array}$} & Evet & $\begin{array}{c}27 \\
(25-30)\end{array}$ & $\begin{array}{c}16 \\
(13-18)\end{array}$ & $\begin{array}{c}17 \\
(16-18)\end{array}$ & $\begin{array}{c}70 \\
(65-77)\end{array}$ & $\begin{array}{c}131 \\
(124,5-138)\end{array}$ \\
\hline & Hayır & $\begin{array}{c}28 \\
(23-31,5)\end{array}$ & $\begin{array}{c}15 \\
(12,5-23)\end{array}$ & $\begin{array}{c}16 \\
(15,5-18)\end{array}$ & $\begin{array}{c}69 \\
(59,5-77,5)\end{array}$ & $\begin{array}{c}129 \\
(125,5-132)\end{array}$ \\
\hline & Z & $-0,221$ & $-0,733$ & $-0,784$ & $-0,682$ & $-1,357$ \\
\hline & $p$ & 0,825 & 0,463 & 0,433 & 0,496 & 0,175 \\
\hline \multirow{4}{*}{$\begin{array}{l}\text { Epidemiyoloji } \\
\text { dersi alma } \\
\text { durumu }\end{array}$} & Evet & $\begin{array}{c}27 \\
(25-29)\end{array}$ & $\begin{array}{c}16 \\
(13-18)\end{array}$ & $\begin{array}{c}16 \\
(16-18)\end{array}$ & $\begin{array}{c}70 \\
(65-76)\end{array}$ & $\begin{array}{c}131 \\
(124-137)\end{array}$ \\
\hline & Hayır & $\begin{array}{c}28 \\
(26-30)\end{array}$ & $\begin{array}{c}15 \\
(12-19)\end{array}$ & $\begin{array}{c}17 \\
(16-18)\end{array}$ & $\begin{array}{c}70 \\
(66-77)\end{array}$ & $\begin{array}{c}132 \\
(128-139)\end{array}$ \\
\hline & Z & $-1,620$ & $-0,010$ & $-0,723$ & $-0,674$ & $-1,689$ \\
\hline & $p$ & 0,105 & 0,992 & 0,470 & 0,501 & 0,091 \\
\hline \multirow{4}{*}{$\begin{array}{l}\text { Tez dişında } \\
\text { herhangi bir } \\
\text { araştırma } \\
\text { deneyimi olma } \\
\text { durumu }\end{array}$} & Evet & $\begin{array}{c}28 \\
(25,5-30)\end{array}$ & $\begin{array}{c}15 \\
(13-18,5)\end{array}$ & $\begin{array}{c}17 \\
(16-19)\end{array}$ & $\begin{array}{c}70 \\
(65,5-77,5)\end{array}$ & $\begin{array}{c}132 \\
(126-138,5)\end{array}$ \\
\hline & Hayır & $\begin{array}{c}27 \\
(25-29,5)\end{array}$ & $\begin{array}{c}16 \\
(12,5-18)\end{array}$ & $\begin{array}{c}16 \\
(16-18)\end{array}$ & $\begin{array}{c}70 \\
(65-75,5)\end{array}$ & $\begin{array}{c}131 \\
(124-136,5)\end{array}$ \\
\hline & Z & $-1,189$ & $-0,229$ & $-1,210$ & $-1,012$ & $-1,454$ \\
\hline & $p$ & 0,235 & 0,819 & 0,226 & 0,311 & 0,146 \\
\hline \multirow{4}{*}{$\begin{array}{l}\text { Bilimsel } \\
\text { yayınları takip } \\
\text { etme durumu }\end{array}$} & Evet & $\begin{array}{c}28 \\
(26-31)\end{array}$ & $\begin{array}{c}16 \\
(13-18)\end{array}$ & $\begin{array}{c}17 \\
(16-19)\end{array}$ & $\begin{array}{c}71 \\
(66-77)\end{array}$ & $\begin{array}{c}132 \\
(128-139)\end{array}$ \\
\hline & Hayır & $\begin{array}{c}26 \\
(23-28)\end{array}$ & $\begin{array}{c}16 \\
(13-18)\end{array}$ & $\begin{array}{c}16 \\
(15-18)\end{array}$ & $\begin{array}{c}68 \\
(63-74)\end{array}$ & $\begin{array}{c}125 \\
(118-132)\end{array}$ \\
\hline & Z & $-4,400$ & $-0,447$ & $-3,201$ & $-2,818$ & $-5,532$ \\
\hline & $p$ & $0,001^{* *}$ & 0,655 & $0,001^{* *}$ & $0,005^{\star \star}$ & $0,001^{* *}$ \\
\hline $\begin{array}{l}\text { Bilimsel } \\
\text { yayınları }\end{array}$ & Yilda bir & $\begin{array}{c}27 \\
(24,5-28,5)\end{array}$ & $\begin{array}{c}17 \\
(13,5-18)\end{array}$ & $\begin{array}{c}16 \\
(15-17)\end{array}$ & $\begin{array}{c}68 \\
(64-73,5)\end{array}$ & $\begin{array}{c}131 \\
(122,5-133)\end{array}$ \\
\hline
\end{tabular}




\begin{tabular}{|c|c|c|c|c|c|c|}
\hline \multirow[t]{6}{*}{ okuma sıklığı } & $\begin{array}{ll}3 & \text { Ayda } \\
\text { bir } & \end{array}$ & $\begin{array}{c}27 \\
(24,75-30)\end{array}$ & $\begin{array}{c}15 \\
(14-18,25)\end{array}$ & $\begin{array}{c}17 \\
(16-18)\end{array}$ & $\begin{array}{c}69 \\
(65-73,75)\end{array}$ & $\begin{array}{c}131 \\
(127-135,25)\end{array}$ \\
\hline & Ayda bir & $\begin{array}{c}28 \\
(27-32)\end{array}$ & $\begin{array}{c}16 \\
(13-18)\end{array}$ & $\begin{array}{c}17 \\
(16-19)\end{array}$ & $\begin{array}{c}72 \\
(66,5-77,5)\end{array}$ & $\begin{array}{c}136 \\
(126-140)\end{array}$ \\
\hline & $\begin{array}{l}\text { Haftada } \\
\text { bir }\end{array}$ & $\begin{array}{c}29 \\
(28-32,5)\end{array}$ & $\begin{array}{c}14,5 \\
(11-18,75)\end{array}$ & $\begin{array}{c}18 \\
(16,25-20)\end{array}$ & $\begin{array}{c}76,5 \\
(70-80,75)\end{array}$ & $\begin{array}{c}137 \\
(131-140)\end{array}$ \\
\hline & $\begin{array}{l}\text { Hiç } \\
\text { okumuyor }\end{array}$ & $\begin{array}{c}25,5 \\
(22,75-27,25)\end{array}$ & $\begin{array}{c}15,5 \\
(12-19,25)\end{array}$ & $\begin{array}{c}16 \\
(15,75- \\
17,25)\end{array}$ & $\begin{array}{c}67,5 \\
(62,75-73,25)\end{array}$ & $\begin{array}{c}126,5 \\
(118,25-131,25)\end{array}$ \\
\hline & $x^{2}$ & 32,318 & 2,721 & 28,416 & 18,948 & 28,532 \\
\hline & $p$ & $0,001^{* *}$ & 0,606 & $0,001^{* *}$ & $0,001^{* *}$ & $0,001^{* *}$ \\
\hline \multirow{4}{*}{$\begin{array}{l}\text { Kanıta dayalı } \\
\text { uygulamalara } \\
\text { ulaşabildiğini } \\
\text { düşünme } \\
\text { durumu }\end{array}$} & Evet & $\begin{array}{c}28 \\
(26-31)\end{array}$ & $\begin{array}{c}15 \\
(12-18)\end{array}$ & $\begin{array}{c}17 \\
(16-19)\end{array}$ & $\begin{array}{c}71 \\
(67,5-78)\end{array}$ & $\begin{array}{c}132 \\
(127-138,5)\end{array}$ \\
\hline & Hayır & $\begin{array}{c}26 \\
(23-28)\end{array}$ & $\begin{array}{c}17 \\
(15-20,5)\end{array}$ & $\begin{array}{c}16 \\
(15-17)\end{array}$ & $\begin{array}{c}66 \\
(62-70)\end{array}$ & $\begin{array}{c}128 \\
(119,5-132,5)\end{array}$ \\
\hline & Z & $-4,649$ & $-4,170$ & $-3,403$ & $-5,369$ & $-3,539$ \\
\hline & $p$ & $0,001^{* *}$ & $0,001^{* *}$ & $0,001^{* *}$ & $0,001^{* *}$ & $0,001^{* *}$ \\
\hline
\end{tabular}

Z: Mann-Whitney U Testi; $x^{2}$ : Kruskal-Wallis Testi ${ }^{*} p<0,05{ }^{{ }^{*}} p<0,01 ;$ BYÖ: Bireysel Yenilikçilik Ölçeği; HÖAGFTÖ: Hemşirelik Öğrencilerinin Araştırmaya, Gelişmelere Farkındalığı ve Tutumu Öl/çeği

Öğrencilerin lisansüstü eğitim özelliklerine göre BYÖ puanları karşılaştıııldığında ise; hemşirelikle ilgili bilimsel yayınları takip eden lisansüstü hemşirelik öğrencilerinin toplam BYÖ, BYÖ fikir önderliği ve risk alma alt boyutu puanlarının takip etmeyenlerden istatistiksel olarak anlamlı düzeyde yüksek olduğu saptandı $(p<0,01)$. Bilimsel yayınları okuma sıklıklarına göre, fikir önderliği alt boyutu puanları açısından istatistiksel olarak anlamlı farklılık saptandı $(p<0,01)$. Ayda bir bilimsel dergi okuyanların fikir önderliği alt boyut puanları, yılda bir $(p=0,009), 3$ ayda bir $(p=0,001)$ okuyanlardan ve hiç okumayanlardan $(p=0,001)$ anlamlı şekilde yüksek saptandı $(p<0,017)$. Haftada bir dergi okuyanların fikir önderliği alt boyut puanları, yılda bir $(p=0,001), 3$ ayda bir $(p=0,002)$ okuyanlardan ve hiç okumayanlardan $(p=0,001)$ anlamlı şekilde yüksek saptandı $(p<0,017)$.

Hemşirelik ile ilgili bilimsel araştırmaların yayınlandığı dergileri okuma sıklıklarına göre risk alma alt boyutu puanları açısından istatistiksel olarak anlamlı farklılık saptandı $(p<0,01)$. Haftada bir bilimsel yayınları okuyanların risk alma alt boyutu puanları, yılda bir $(p=0,001), 3$ ayda bir $(p=0,004)$, ayda bir $(p=0,003)$ bilimsel yayın okuyanlardan ve hiç bilimsel yayın okumayanlardan $(p=0,001)$ anlamlı şekilde yüksek saptandı $(p<0,017)$. Bilimsel yayınları okuma sıklıklarına göre BYÖ toplam puanları açısından istatistiksel olarak anlamlı farklılık saptandı $(p<0,01)$. Buna göre haftada bir bilimsel yayın okuyanların BYÖ toplam puanları, yılda bir $(p=0,002), 3$ ayda bir $(p=0,003)$, ayda bir $(p=0,008)$ bilimsel yayın okuyanlardan ve hiç bilimsel yayın okumayanlardan $(p=0,001)$ anlamlı şekilde yüksek saptandı $(p<0,017)$. Kanıta dayalı uygulamalara nasıl ulaşacağını bildiğini düşünen öğrencilerin BYÖ toplam puanları, BYÖ fikir önderliği, risk alma alt boyutu puanları, bilmediğini düşünen öğrencilerden istatistiksel olarak anlamlı düzeyde yüksek saptandı $(p<0.01)$. Ayrıca, kanıta dayalı uygulamalara ulaşmayı bilmediğini düşünen öğrencilerin, değişime direnç alt boyut puanları, bildiğini düşünen öğrencilerden istatistiksel olarak anlamlı düzeyde yüksek saptandı $(p<0,01)$ (Tablo 4).

\section{Tartışma ve Sonuç}

Bilim ve teknolojik gelişmelerle birlikte nitelikli insan gücü yetiştirmek, lisansüstü eğitimin tartışılmaz önceliği haline gelmiştir [12]. Araştırma ve klinik uygulama arasında oluşan boşluğun doldurulması, araştırmanın klinik uygulamaya entegre edilmesi hemşirelerde ve akademisyenlerde araştırma bilinci ve farkındalığın oluşturulması ile mümkündür. Lisansüstü eğitim programlarının nitelikli insan gücü yetiştirme, bilgi üretme, yayma ve araştırma gibi fonksiyonları vardır [12]. Lisansüstü eğitimin kalitesi, ülkelerin gelişmişlik düzeyi ve kaynakların etkin kullanımı ile ilişkilidir [6]. Ancak, dünyada [5] ve Türkiye'de lisansüstü eğitim programlarına alınan yüksek lisans ve doktora öğrencilerin sayısı giderek artmaktadır [13]. Bu nedenle, lisansüstü hemşirelik öğrencilerinin sayısı artarken, yetkinliklerinin de 
artırıması için öğrencilerin yenilikçilik özellikleri ile araştırmaya yönelik farkındalık ve tutuma sahip olmaları, mezuniyetten önce edinmeleri gereken hayati becerilerdir. Ancak o zaman, değişen ve gelişen dünyanın intiyaçlarını karşılayabilecek niteliklere sahip hemşirelerin ya da akademisyenlerin yetiştirilmesi mümkün olabilir [14,15]. Bu çalışma, lisansüstü öğrencilerinin HÖAGFTÖ ile BYÖ arasındaki ilişkiyi ve etkileyen faktörleri ortaya koymak amacıyla gerçekleştirildi.

Bu çalışmada, lisansüstü hemşirelik öğrencilerinin HÖAGFTÖ ile BYÖ toplam puanları arasında orta düzeyde bir ilişki saptanırken HÖAGFTÖ ile BYÖ fikir önderliği alt boyutu arasında zayıf ve risk alma alt boyutları arasında orta düzeyde ve pozitif yönde bir ilişki olduğu saptandı. Öğrencilerin araştırma farkındalık ve tutumları ile fikir önderliği alt boyutu arasında zayıf da olsa var olan pozitif yöndeki ilişki, öğrencilerin lisansüstü eğitimi boyunca uzmanlık alanlarına yönelik kazandıkları bilgi ve becerileri uygulama alanlarına aktararak yenilikçi fikirlerin geliştirilmesine önderlik yapabileceklerini düşündürmektedir. Aynı şekilde, araştırma farkındalık ve tutumları ile risk alma alt boyutları arasındaki orta düzeydeki ilişki de öğrencilerin araştırma farkındalık ve tutumları geliştikçe, BYÖ'nin ve risk alma davranışlarının da paralel olarak geliştiğini göstermekle birlikte beklenen bir sonuçtur. Bu sonuç, öğrencilerin ilgi duydukları uzmanlık alanında aldıkları eğitimler ile kendilerini geliştirme isteklerinin olduğunu, meslekte yenilikçi yaklaşımları kullanmaya ve risk almaya yatkın olduklarını göstermektedir. HÖAGFTÖ toplam puanları ile BYÖ değişime direnç alt boyutu puanları arasında negatif yönde ve zayıf bir ilişki olduğu belirlendi. Öğrencilerin araştırma farkındalık ve tutumları olumlu yönde artıkça, değişime dirençlerinin de azalmasının, güncel ve kanıta dayalı bilimsel bilgiler ile kendilerini sürekli güncellemeye ve yaşam boyu geliştirmeye açık olduklarını göstermektedir. Araştırma kapsamına alınan öğrencilerin lisansüstü eğitimlerini sürdüren ve çoğunluğunun klinik alanlarda çalışan hemşireler olduğu dikkate alındığında, çalıştıkları kurumlarda, bilimsel ve kanıta dayalı bilgileri klinik uygulamaya aktarma eğiliminde olduklarını düşündürmektedir.

Bu çalışmada, lisansüstü hemşirelik öğrencilerinin araştırma, gelişmelere yönelik farkındalık ve tutumları yüksektir. Bu sonuç, lisansüstü hemşirelik öğrencilerinin beklenildiği gibi lisans öğrencilerinden [15-17] daha olumlu tutuma sahip olduklarını göstermektedir. Araştırmaya yönelik farkındalığın değerlendirildiği ve 1103 hemşirenin örnekleme alındığı bir çalışmada ise, yüksek lisans ve doktora mezunu olan hemşirelerin ortalama "tutum" puanlarının daha yüksek olduğu belirlenmiştir [14].

Literatürde, lisans öğrencilerinin çoğunluğunun BYÖ'lerinin sorgulayıcı [18,19] kuşkucu [2] ya da gelenekselci özellikleri olduğu [20], bu çalışmada ise lisansüstü hemşirelik öğrencilerinin BYÖ'lerinin bir üst düzeye geçtiği ve öncü özellikler gösterdikleri saptanmıştır. Bu sonuç, hemşireler ile yapılan çalışma ile benzerlik göstermektedir [19]. Bu benzerliğin nedeni, araştırma kapsamına alınan lisansüstü hemşirelik öğrencilerinin çoğunluğunun aynı zamanda sağlık kurumlarında farklı pozisyonlarda çalışan hemşireler olmasından kaynaklanmış olabilir.

Bu çalışmada, kadınların araştırma farkındalık ve tutumları erkeklere göre daha yüksekti. Babalis ve ark. (2012) [3] lisans öğrencileri ile yaptıkları çalışmada, erkek ve kadın öğrencilerin araştırmaya karşı olumlu tutumlarının olduğunu, ancak araştırma tutumları açısından fark olduğunu, erkeklerin bireysel kararlar alabilecekleri araştırmaları tercih ederken, kadınların daha çok net ve açık hedefleri olan araştırmaları tercih ettiklerini ortaya koymuştur. Ayrıca, bu çalışma ile benzer şekilde cinsiyete göre öğrencilerin yenilikçi ve yaratıcı özellikleri arasında fark olmadığını ortaya koymuştur.

Araştırma görevlisi/öğretim görevlisi olarak çalışanların; araştırma farkındalık ve tutumlarının ve bireysel yenilikçilik özelliklerinin risk alma alt boyutu puanları, hemşire, servis sorumlu hemşiresi olarak ve diğer görevlerde çalışanlardan daha yüksekti. Bu farkın nedeni, araştırma görevlisi/öğretim görevlisi olarak çalışanların akademik ortamda çalışmaları, akademik kariyer gelişimleri için kendilerinden araştırma yapmalarının beklenmesi, deneyimli akademisyenler ile çalışma fırsatı bulmaları ve öğrencilere rol model olmalarının beklenmesinden kaynaklanmış olabilir.

Bu çalışmada, lisansüstü hemşirelik öğrencilerinin yarısından fazlasının tezleri dışında bir araştırma deneyimine sahip olmadıkları belirlendi. Lisansüstü eğitimleri sürecinde öğrencilerin kendi tezleri dışında bir araştırma sürecine katılmaları ve hemşireliğin profesyonel rollerinden bir tanesi olan araştırmacı rolüne hazırlanmaları, araştırma bilgi ve becerilerini kazanmaları önemlidir. Öğrencilere araştırma becerilerinin kazandırılmasında tez danışmanların önemli rolleri vardır. Öğrencileri ile tez dışında araştırmalar planlayarak becerilerini geliştirebilirler [4]. Böylece öğrenciler kendi uzmanlık alanında araştırmalar planlayabilir ve yeni kanıtlar üretilmesine katkıda bulunabilirler. Magali (2019) 
[21] çalışmasında, lisansüstü hemşirelik öğrencilerinin çoğunluğunun araştırma yazma becerilerinin yetersiz olduğunu ve bu nedenle araştırmalarını yazma sürecinde zorluk yaşadıklarını saptamıştır. Araştırmanın yapıldığı kurumda öğretim elemanı başına düşen lisansüstü öğrenci sayısının yüksek olması, öğrencilerin çoğunluğunun eğitimlere devam ederken hemşire olarak alanda çalışmaları ve yarı zamanlı çalışma imkanlarının olmaması gibi sorunlar öğrencilerin araştırma yapmalarındaki engeller olabilir.

Lisansüstü hemşirelik öğrencileri ancak araştırma deneyimini yaşadıklarında araştırma kavramını ve önemini anlayabilmektedirler [22]. Çalışmada, araştırma deneyimi olan öğrenciler ile olmayan öğrenciler arasında ölçek puanları açısından bir farklılık olmadığı da saptandı. Ünver ve ark. [23] lisans öğrencileri ile yaptığı araştırması, bu çalışmanın aksine araştırma deneyimi olan öğrencilerin araştırmaya yönelik daha olumlu tutuma sahip olduklarını ortaya koymuştur. Aynı şekilde, Türkiye'de yapılan bir çalışmada, lisans tezi yazan öğrencilerin diğer öğrencilere göre araştırmaya yönelik daha olumlu tutumlar geliştirdiği saptanmıştır [22] Bu çalışmada örnekleme dahil edilen öğrencilerin, yaş ortalamasının 29 ve meslekte toplam deneyim sürelerinin 6,5 yıl olduğu dikkate alındığında; öğrencilerin henüz araştırmacı rolüne hazırlanamadıkları ve araştırma becerilerini tam olarak geliştiremedikleri söylenebilir.

Lisansüstü hemşirelik öğrencilerinin yarısından fazlasının uzmanlık alacağı alan ile ilgili bilimsel yayınları takip ettiği, ancak yayınları okuma sıklığı incelendiğinde haftada bir okuyanların oranının düşük olduğu belirlendi. Magali (2019) [22] çalışmasında lisansüstü öğrencilerinin araştırma oryantasyonlarının ve okuma kültürlerinin olmamasından dolayı, tezlerini zamanında bitiremediklerini ortaya koymuştur. Lisansüstü hemşirelik öğrencilerinin kanıta dayalı uygulamalara ulaşmayı bilmesi ve bu kanıtları araştırmalarında kullanması beklenmektedir. Bu çalışmada öğrencilerin yaklaşık dörtte üçü kanıta dayalı uygulamalara ulaşabildiğini düşünmektedir. Kanıta dayalı uygulamalara nasıl ulaşacağını bildiğini düşünenlerin de araştırma farkındalık ve tutumlarının yüksek, bireysel yenilikçilik özellikleri ölçek toplam puanları, BYÖ fikir önderliği ve risk alma alt boyutu puanlarının, bilmediğini düşünenlerden yüksek olması da beklenen bir sonuç olmakla birlikte yapılan çalışmalar ile benzerlik göstermektedir (23). Sonuç olarak; kadınlar, araştırma görevlisi/öğretim görevlisi olarak görev yapanlar, bilimsel yayınları takip edenler, bilimsel yayınları üç ayda bir okuyanlar ve kanıta dayalı bilgilere ulaşabildiğini düşünen lisansüstü hemşirelik öğrencileri yenilikçi özelliklere sahip olmakla birlikte daha olumlu araştırma farkındalık ve tutumları mevcuttur.

\section{Sonuçlar}

Lisansüstü hemşirelik öğrencilerinin yenilikçilik özellikleri öncü olup, araştırmaya yönelik olumlu tutumları mevcuttur. Ayrıca, lisansüstü hemşirelik öğrencilerinin bireysel yenilikçilik özellikleri ile araştırma farkındalık ve tutumları arasında orta düzeyde bir ilişki vardır. Lisansüstü hemşirelik öğrencilerinin bireysel yenilikçilik özelliklerini, araştırma farkındalık ve tutumlarını daha fazla geliştirmek için; eğitimlerinde teknoloji içeren eğitim yöntemlerinin kullanılması, araştırma bilgi ve becerilerini geliştirecek yenilikçi yaklaşımların eğitim programlarına entegre edilmesi, alanları ile ilgili bilimsel yayınları takip etme alışkanlıklarının kazandıııması ve hemşirelik lisansüstü eğitiminde ortak stratejik araştırma planlarının geliştirilmesi faydalı olabilir. Lisansüstü hemşirelik öğrencilerinin BYÖ ve HÖAGFTÖ etkileyebilecek ve bu çalışmada ele alınmayan farklı faktörlerin büyük örneklemlerde araştırılması önerilir.

\section{Araştırmanın Sınırııı̆ı}

$\mathrm{Bu}$ araştırmanın tek bir vakıf üniversitesinde yapılması ve soruların öğrencilerin yanıtlarına dayalı olması bir sınırlılıktır ve elde edilen sonuçlar genellenemez.

\section{Teşekkür}

Çalışmaya katılmayı kabul eden lisansüstü hemşirelik öğrencilerine katkılarından dolayı teşekkür ederiz.

\section{Kaynakça}

[1] Saral DG, Reyhanlioğlu D. An analysis of educational faculty students' research self-efficacy in terms of a number of variables. Procedia Soc Behav Sci 2015; (174) : 1138-45. 
[2] Erol Ö, Yacan L, Hayta R, Şahin I, Yağcı M. Hemşirelik öğrencilerinin yenilikçilik özellikleri ve etkileyen faktörler. Hemşirelikte Eğitim ve Araştırma Dergisi 2018; 15 (3): 142-146.

[3] Babalis T, Xanthakou Y, Kaila M, Stavrou N. Research attitude and innovative-creative thinking: Differences between undergraduate male and female students. Procedia Soc Behav Sci 2012; (69): 1452-61.

[4] Hajihosseini F, Tafreshi MZ, Hosseini M, Baghestani AR. Postgraduate nursing students' expectations of their supervisors in Iran: A qualitative study. Iran J Nurs Midwifery Res 2018; 23 (2): 98-104.

[5] Havenga $Y$, Sengane ML. Challenges experienced by postgraduate nursing students at a South African university. Health SA 2018; (23) : 1-9.

[6] Karaman S, Bakırcı F. Türkiye'de lisansüstü eğitim: Sorunlar ve çözüm önerileri. Sosyal Bilimler Araştırmaları Dergisi 2010; 5 (2): 94-114.

[7] Sarıoğlu Kemer A, Altuntaş S. Bireysel Yenilikçilik Ölçeği'nin Hemşireliğe Uyarlanması: Türkçe GeçerlikGüvenirlik Çalışması. Hemşirelikte Eğitim ve Araştırma Dergisi 2017; 14 (1): 52-61.

[8] Drennan J, Clarke M. Coursework master's programmes: the student's experience of research and research supervision. Stud in High Educ 2009; 34 (5): 483-500.

[9] Lev EL, Kolassa J, Bakken LL. Faculty mentors' and students' perceptions of students' research self-efficacy. Nurse Educ Today 2010; 30 (2): 169-74.

[10] Hurt HT, Joseph K, Cook CD. Scales for the measurement of innovativeness. Hum Commun Res 1977; 4 (1): 58-65.

[11] Temel AB, Uysal A, Erkin Ö, Koçer A. Hemşirelik öğrencilerinin araştırmaya, gelişmelere farkındalığı ve tutumu ölçeğinin Türkçe formunun geçerliliği, güvenilirliği. Dokuz Eylül Üniversitesi Hemşirelik Yüksekokulu Dergisi (online). 2008; 1 (2): 108-23.

[12] Bozan M. Lisansüstü eğitimde nitelik arayışları. Sosyal ve Beşeri Bilimler Dergisi 2012; 4 (2): 177-87.

[13] Kocaman G, Arslan Yürümezoğlu H. Türkiye'de Hemşirelik Eğitiminin Durum Analizi: Sayılarla Hemşirelik Eğitimi (1996-2015). J Higher Educ \& Science/Yükseköğretim ve Bilim Dergisi 2015; 5 (3): 255-262.

[14] Watanabe Y, Oe M, Takemura Y, Sasaki M, Onishi M, Kanda K, et al. Four factor Research A wareness Scale for Nurses in Japanese: Instrument development study. Jpn J Nurs Sci 2013; 10 (2): 232-41.

[15] Ünsal A, Karakurt P, Tanrıverdi D. Farklı okullarda eğitim gören hemşirelik öğrencilerinin araştırmaya, gelişmelere farkındalığı ve tutumunun belirlenmesi. Balıkesir Sağlık Bilimleri Dergisi 2014; 3 (2): 87-93.

[16] Şener DK, Arslan S, Cangür Ş, Aydın M. Bir grup lisans hemşirelik öğrencisinin mesleki araştırma ve gelişmelere yönelik farkındalık ve tutumları. Türkiye Klinikleri J Nurs Sci 2016; 8 (4): 317-24.

[17] Dinçer S, Eker Ö, Deniz Y, Karaçay P, Yazıcı Ö. Assessment of Nursing Students' Attitudes and Awareness Towards Professional Research and Development. Arc Health Sci Res 2020; 7 (3): 264-70.

[18] Ertuğ N, Kaya H. Hemşirelik öğrencilerinin bireysel yenilikçilik profilleri ve yenilikçiliğin önündeki engellerin incelenmesi. Hemşirelikte Eğitim ve Araştırma Dergisi 2017; 14 (3): 192-197.

[19] Başoğlu $M$, Edeer $A D$. X ve $Y$ kuşağındaki hemşirelerin ve hemşirelik öğrencilerinin bireysel yenilikçilik farkındalıklarının karşılaştırıması. Gümüşhane Üniversitesi Sağlık Bilimleri Dergisi 2017; 6 (4): 77-84.

[20] Utli H, Doğru BV. Hemşirelik ve ebelik öğrencilerinin bireysel yenilikçilik özelliklerinin değerlendirilmesi. Gümüşhane Üniversitesi Sağlık Bilimleri Dergisi 2018; 7 (3): 23-32.

[21] Magali J. Research projects writing skills and other challenges faced the master and PhD students at the open University Tanzania. Int J Soc Sci Res 2019; 7 (1): 41-57.

[22] Uysal Toraman A, Hamaratçılar G, Tülü B, Erkin Ö. Nursing students' attitudes toward research and development within nursing: Does writing a bachelor thesis make a difference? Int J Nurs Pract 2017; 23 (2): e12517.

[23] Ünver S, Semerci R, Özkan ZK, Avcıbası I. Attitude of nursing students toward scientific research: A crosssectional study in Turkey. J Nurs Res 2018; 26 (5): 356-61. 